14. Schroeck J. M. Customer analytics making the difference in CRM: Customer analytics amplify the value of integrated CRM solutions // Business Intelligence. 2004. Vol. 6. P. 16-19.

15. Shulman Sh., Elaine H. M. Reshaping the Pharmaceutical Distribution Network // Journal of Pharmaceutical Marketing \& Management. 2005. Vol. 12. P. 34-45.

Дата надходження рукопису 15.01.2019

Olga Posilkina, Doctor of Pharmacy, Professor, PhD, Head of Department, Department of Management and Economics of Enterprise, National University of Pharmacy, Pushkinska str., 53, Kharkiv, Ukraine, 61002

Zhanna Mala, Postgraduate Student, Department of Management and Economics of Enterprise, National University of Pharmacy, Pushkinska str., 53, Kharkiv, Ukraine, 61002

Iryna Bondarieva, $\mathrm{PhD}$, Associate Professor, Department of Pharmaceutical Marketing and Management, National University of Pharmacy, Pushkinska str., 53, Kharkiv, Ukraine, 61002

УДК 543.42:615.322:615.451.1/.2

DOI: $10.15587 / 2519-4852.2019 .157947$

\title{
DEVELOPMENT OF THE PROCEDURE OF QUANTITATIVE DETERMINATION OF THE BIOLOGICAL ACTIVE SUBSTANCES IN THE EXTRACT OF A BUPLEURUM AUREUM IN THE COMPOSITION OF A COMBINED DOSAGE FORM
}

\author{
(C) A. Glushchenko, I. Bezruk, N. Bevz, L. Ivanauskas, V. Georgiyants
}

На сьогодні все більшого розповсюдження набувають комбіновані лікарські засоби. Поєднання активних фармачевтичних інгредієнтів необхідно для підвищення терапевтичного ефекту або скорочення терміну лікування, або запобігання можливих ускладнень.

Метою роботи - є розробка методики кількісного визначення біологічно активних сполук сухого екстракту ласкавцю золотистого у складі комбінованої лікарської форми сиропу у суміші з лоратадином.

Методи. Ідентифікацію флавоноїдів в екстракті здійснювали методом ВЕРХ. Для визначення кількісного вмісту речовин флавоноїдної будови використовували метод абсорбиійної спектрофотометрії у видимій ділянці спектру, який базується на утворенні забарвлених комплексів флавоноїдів з розчином алюмінію хлориду у кислому середовищі.

Результати дослідження. У результаті проведених досліджень розроблено спектрофотометричну методику кількісного визначення суми флавоноїдів у комбінованому сиропі з лоратадином та екстрактом ласкавия сухим. Методом ВЕРХ визначено флавоноїди, щзо містяться в екстракті. Отримані забарвлені комплекси спиртових вилучень із сиропу після реакиії взаємодії з розчином алюмінію хлориду в очтовокислому середовищі характеризувалися наявністю максимумів поглинання за довжини хвилі 412 нм. Вплив фонового поглинання є незначущзим $\delta_{\text {поіе }}=0,25 \% \leq$ тах $\delta=0,51 \%$. Вивчені валідаційні характеристики методики свідчать про лінійну залежність кількості суми флавоноїдів у перерахунку на рутин 8 діапазоні концентрації екстракту ласкавцью золотистого в сиропі від $80 \%$ до 120 \%, так як величина

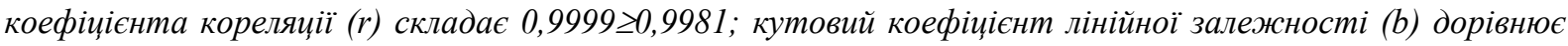
0,9947, вільний член лінійної залежності (a) - 0,52 $\leq 1,60$. Методика прецизійна, оскільки значення відносного довірчого інтервалу менше критичного значення для збіжності результатів: $\Delta \%=0,37 \leq 2,60 i$ виконусться критерій незначущості систематичної похибки $\delta=0,01$.

Висновки. Методом ВЕРХ встановлено наявність у сухому екстракті надземної частини ласкавцю золотистого речовин флавоноїдної будови, щуо спонукало до стандартизачії діючої речовини у сиропі за сумою саме иих біологічно активних сполук. Розроблено спектрофотометричну методику кількісного визначення у видимій ділянці суми флавоноїдів у перерахунку на рутин у комбінованій лікарській формі у вигляді сиропу у присутності іншого діючого інгредієнту лоратадину

Ключові слова: Ласкавець золотистий, сироп, хімічний склад, флавоноїди, спектрофотометрія у видимій діляниі, $B E P X$

\section{Introduction}

Scientists call allergies, due to their excessive prevalence, as the epidemic of the XXI century. The number of patients with allergies increases every year, in particular in Ukraine. Symptomatic drug therapy for allergy is usually carried out by blockers of H1-histamine and serotonin receptors, glucocorticoids, membrane stabilizers and anti-mediators, and others [1].

Today, increasingly, for the treatment of allergic manifestations, plant-based products are used, which can be conditioned by an increase in the interest of the population in preparations based on plant material and 
the spread of herbal medicinal products among the population.

\section{Formulation of the problem in a general} way, the relevance of the theme and its connection with important scientific and practical issues

A new dosage form has been developed in the form of syrup, which, as active substances, includes the H1-histamine and serotonin receptor blocker loratadine and the dry extracts of the above-ground part of the $\mathrm{Bu}$ pleurum aureum. Medicinal products from Bupleurum aureum due to the presence of the sum of biologically active substances improve the production of bile, stimulate the allocation of pancreatic and gastric juices and as a result show hepatoprotective, bile-forming, antiinflammatory and normalize the biochemical composition of bile [2]. To provide additional anti-inflammatory, hepatoprotective and antioxidant properties, the plant component was introduced into the formulation [3, 4].

\section{Analysis of recent studies and publications in which a solution of the problem and which draws on the author}

The aboveground part of the Bupleurum aureum contains saikosaponins, essential oils, ascorbic acid, $\beta$ carotene, tannins, alkaloids, flavonoids, phytosterols, among which the majority are substances of the flavonoid structure [2].

For the quantitative determination of flavonoids, the method of differential spectrophotometry is often used $[5,6]$. The literature describes methods of spectrophotometric determination of flavonoids in plant material based on the reaction of flavonoids from aluminum chloride. The main advantage of this method is the possibility of selective determination of flavonoids in complex mixtures without prior separation [7].

\section{Allocation of unsolved parts of the general problem, which is dedicated to the article}

A new combination dosage form is proposed in the form of syrup, for further application of which the necessary condition is the development of methods for quality control of active components.

\section{Formulation of goals (tasks) of Article}

The aim of the work was to develop a method for quantitative determination of the biologically active compounds of the dry extract of Bupleurum aureum as a part of the combined dosage form in the form of a syrup in the presence of another active pharmaceutical ingredient loratadine and auxiliary substances.

\section{Statement of the basic material of the study (methods and objects) with the justification of the results}

The experimental series of syrup (No. 31218), dry extracts of the aboveground part of Bupleurum aureum L., loratadine (No. LRD / 0909180, manufactured by Vasud and Pharma Chem Limited), auxiliary components of syrup, RS routine (RS SPHU, (No. 4; $99.87 \%$ ).

Reagents that meet the requirements of the State Pharmacopoeia of Ukraine [8], grade A glassware, analytical equipment: liquid chromatograph Shimadzu Nex- era X2 LC-30AD, thermo scientific Evolution 60S spectrophotometer (USA), AXIS scales (Poland) also were taken.

Sample preparation. $0.5 \mathrm{~g}$ extract were weighed into a volumetric flask and extracted with methanol $(10 \mathrm{~mL})$ in an ultrasonic bath at room temperature $\left(20 \pm 2{ }^{\circ} \mathrm{C}\right)$ for $30 \mathrm{~min}$. The solutions were filtered through a membrane filter $(0.45 \mu \mathrm{m})$ prior to use.

Liquid chromatography separation was performed using a Shimadzu Nexera X2 LC-30AD HPLC system (Shimadzu, Japan) composed of a quaternary pump, an on-line degasser, a column temperature controller, the SIL-30AC autosampler (Shimadzu, Japan); the CTO20AC thermostat (Shimadzu, Japan) as well as the SPDM20A diode array detector (DAD). Another instruments such as Ultrasonic Cleaner Set for ultra-sonication using (Wise Clean WUC-A06H, Witeg Labortechnik GmbH, Germany), Libra UniBloc AUW120D (Shimadzu Analytical Scale, Japan); pH-meter - Knick Electronic Battery-operated pH Meter 911 PH (Portamess, Germany), class A analytical vassals that meets requirements of the SPhU (SPhU, 2015) were used in the study.

Chromatographic separation was carried out using an ACE C18 column $(250 \mathrm{~mm} \times 4.6 \mathrm{~mm}, 5.0 \mu \mathrm{m}$; Pennsylvania, USA). Elution was performed at a flow rate of $1 \mathrm{ml} / \mathrm{min}$. The binary solvent system of the mobile phase consists of solvent A ( $0.1 \%$ acetic acid in water) and solvent B (acetonitrile). All solvents were filtered through a $0.23 \mu \mathrm{m}$ membrane filter after ultrasonic degassing. A linear gradient program was applied as follows: $0-8 \mathrm{~min}$, 5-15 \% B; 8-30 min, 15-20\% B; 30-48 min, 20-40\% B; 48-58 min, 40-50\% B; 58-65 min, 50\%; 65-66 min, $50-95 \%$ B. The column temperature was constant $25^{\circ} \mathrm{C}$. The injection volume of sample solution was $20 \mu \mathrm{L}$. The chromatograms were recorded at 269, 360 and $370 \mathrm{~nm}$.

The method of quantification of flavonoids in a combined syrup was previously developed on modelled mixes, for which the investigated extract, loratadine and auxiliary components of syrup were used.

We studied the validation characteristics specificity, linearity, accuracy and precision of the following methodology:

Studied solution. $3.000 \mathrm{~g}$ (exact weigh) of the syrup are placed in a round-bottomed flask of $50 \mathrm{ml}$ capacity, $10 \mathrm{ml}$ of $70 \%$ ethanol are added and boiled in a water bath for 60 minutes. After cooling, the resulting solution is filtered in a volumetric capacity of $10.0 \mathrm{ml}$, the residue is rinsed with the same solvent and filtered through the same filter. $1.0 \mathrm{ml}$ of the resulting solution is placed in a $25.0 \mathrm{ml}$ volumetric flask, add $2.0 \mathrm{ml}$ of aluminum chloride reagent and bring the solution to $5 \%$ solution of acetic acid in $96 \%$ ethanol.

Compensation solution. $1.0 \mathrm{ml}$ of the resulting solution of the aboveground part or $2.0 \mathrm{ml}$ of the resulting solution of the extract is placed in a $25.0 \mathrm{ml}$ volumetric flask and the volume of the solution is adjusted to $5 \%$ aqueous acetic acid in $96 \%$ ethanol.

Reference solution. $0.025 \mathrm{~g}$ (exact weigh) of RS routine dissolved in $30 \mathrm{ml}$ of $96 \%$ alcohol while heated in a water bath, cool and bring the volume of solution to the same solvent to $50.0 \mathrm{ml}$. To $1.0 \mathrm{ml}$ of the resulting solution, add $1.0 \mathrm{ml}$ of aluminum chloride reagent and bring the solution to $5 \mathrm{ml}$ of acetic acid in ethanol to $25.0 \mathrm{ml}$. 
Compensation solution. $1 \mathrm{ml}$ of the initial solution is adjusted with a solution of $5 \%$ of acetic acid in ethanol to a volume of $25.0 \mathrm{ml}$.

The optical density of the obtained test solutions and the standard routine sample solution were determined on a spectrophotometer at a wavelength of $412 \mathrm{~nm}$ in a cuvette with a thickness of $10 \mathrm{~mm}$.

The content of the amount of flavonoids (x), as a percentage, in terms of routine, is calculated by the formula:

$$
x=\frac{A_{1} \cdot m_{o} \cdot V_{2} \cdot V_{4} \cdot V_{6} \cdot 100}{A_{o} \cdot m_{1} \cdot V_{1} \cdot V_{3} \cdot V_{5} \cdot(100-d)} \cdot 100 \%
$$

where $\mathrm{A}_{0}$ - optical density of a standard rutine solution at a wavelength of $412 \mathrm{~nm}$;

$A_{1}$ - optical density of a studied solution at a wavelength of $412 \mathrm{~nm}$;

$\mathrm{m}_{0}$ - the sample weight of the rutin RS, g; $\mathrm{m}_{1}$ - the sample weight of the syrup RS, $\mathrm{g}$;

$\mathrm{V}_{1}-\mathrm{V}_{5}$ - volumes of volumetric flasks and an aliquot for preparation of extraction of the Bupleurum aureum extract from the syrup and rutin $\mathrm{RS}, \mathrm{ml}$.

Quantitative content of loratadine in the combined dosage form was determined by spectrophotometric method in a $0.1 \mathrm{M}$ hydrochloric acid solution at a wavelength of $278 \mathrm{~nm}$ after the previous removal of other active and auxiliary substances of the syrup by an organic layer $[9,10]$.

To determine the markers, a preliminary chromatographic evaluation of the flavonoid content was carried out in the azure sausage extract. According to the experimental data (Fig. 1, Table 1), the group of flavonoids in the extract is represented by such substances as hyperoside, isoquercitrin, quercetin and kaempferol. The largest amount was observed for isoquercitrin, which is logical because it is well soluble in water.

\section{$<$ Chromatogram>}

mAU

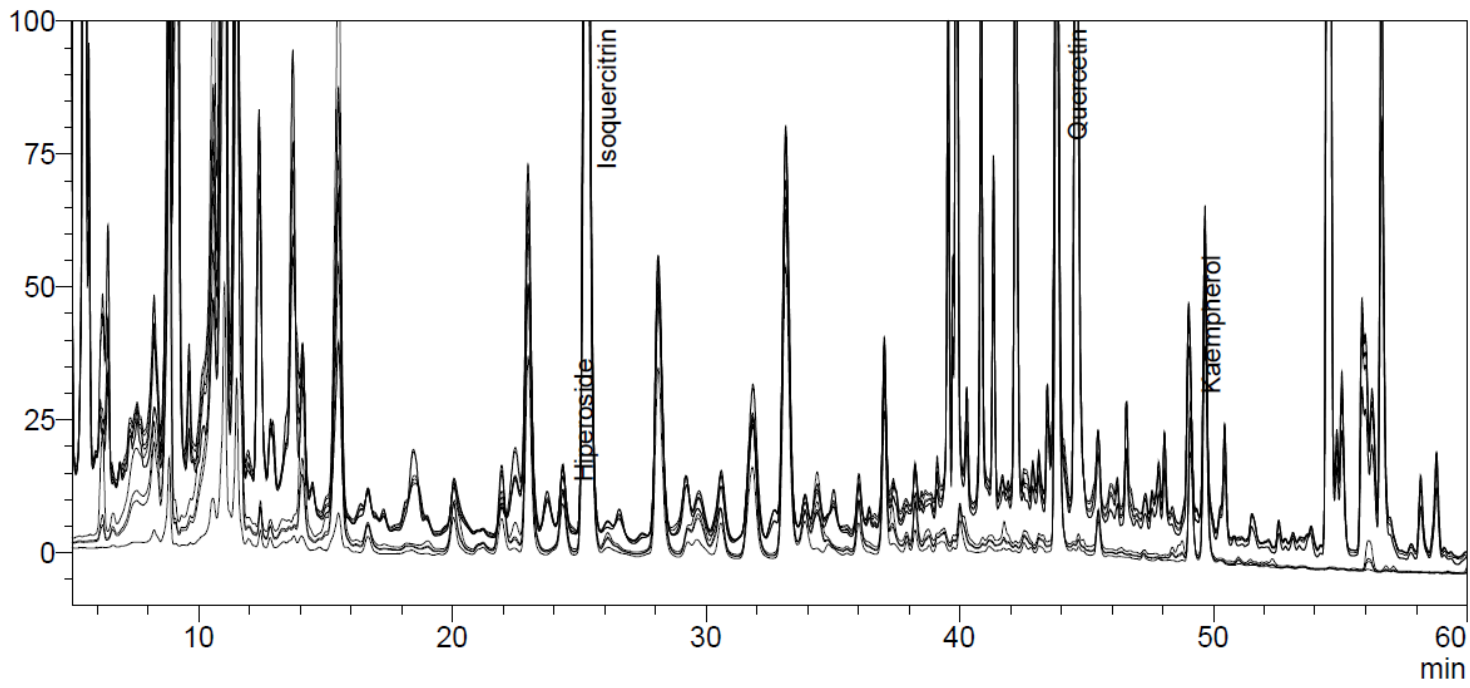

Fig. 1. Chromatogram of the preliminary estimation of the content of substances of the flavonoid structure in the dry extract of the Bupleurum aureum

Table 1

The content of substances of flavonoid nature in the extract of the Bupleurum aureum, established by the method of HPLC

\begin{tabular}{|c|c|c|c|c|c|}
\hline No. & Compound & Wavelength, $\mathrm{nm}$ & Retention time & Area & $\begin{array}{c}\text { Concentration, } \\
\mathrm{mkg} / \mathrm{ml}\end{array}$ \\
\hline 1 & Hiperoside & 350 & 24.363 & 210587 & 9.249 \\
\hline 2 & Isoquercitrin & 350 & 25.267 & 3686944 & 152.572 \\
\hline 3 & Quercetin & 370 & 43.830 & 2061613 & 50.255 \\
\hline 4 & Kaempherol & 370 & 49.101 & 321019 & 10.680 \\
\hline
\end{tabular}

The biologically active substances of a dry extract of the Bupleurum aureum as a part of syrup are proposed to be standardized in terms of content of flavonoid nature substances in terms of rutin in accordance with the requirements of the SPHU. The choice of the rutin is because it is available as an RS, as well as the fact that it is the same with isoquercitrin aglycon - quercitrin. In view of this, the character of their absorption spectra will be the same. In determin- ing the quantitative content of the amount of flavonoids, a common spectrophotometric technique based on the reaction with a solution of aluminum chloride in an acidic medium was used. To determine the effect on the nature of the absorption spectrum of the resulting complex, a reaction with a solution of aluminum chloride, a combined syrup, a solution of extract in syrup (without loratadine) and placebo (Fig. 2) was performed. 


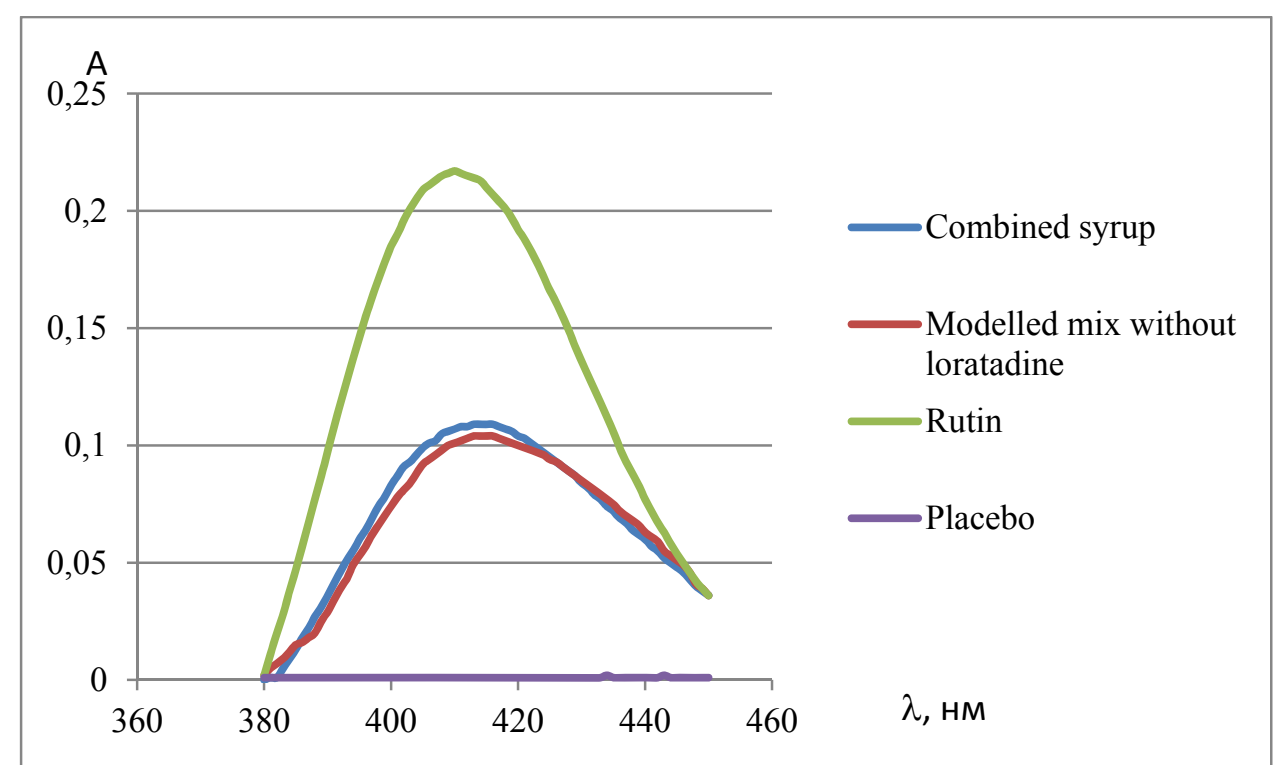

Fig. 2. Absorption spectra of absorption of solutions 1 - rutin; 2 - combined syrup; 3 -modelled mix without loratadine; 4 - placebo

The obtained results (Fig. 2) indicate the possibility of detecting substances of the flavonoid structure in the combined syrup and the absence of the effect of loratadine and auxiliary substances of syrup.

According to the requirements of the SPHU, the validation characteristics of the method of determining the sum of flavonoid structure substances in the syrup, calculated on a rutin basis by the absorption spectrophotometry method, were included for inclusion in the analytical documentation $(\max \Delta \mathrm{As} 1.60 \%$ ). Validation of the methodology was carried out according to the following indicators: specificity, linearity, correctness and precision [8].

The specificity of the method was confirmed by the presence of a combined syrup and dry extract absorbing spectrum of Bupleurum aureum in $70 \%$ of ethanol after absorption spectrum of aluminum chloride at absorption peaks at a wavelength of $412 \pm 2 \mathrm{~nm}$. The position of the maximums of absorption coincides with the position of the maximum absorption of the solution of the rutin comparison (Fig. 3). The effect of background absorption is insignificant $\delta_{\text {noise }}=0.25 \%$, max $\delta=0.51 \%$. All this became a prerequisite to standardize the dry extract of Bupleurum aureum in combined syrup by the sum of substances of the flavonoid structure in terms of rutin.

Linearity, correctness and precision studies were studied on model mixes containing 9 different concentrations of dry extract of Bupleurum aureum in the range of application of the proposed analytical method for quantitative determination. During the determination of the linearity of the method, 9 solutions were prepared that covered the range of concentrations from 80 to $120 \%$ of the proposed and measured optical density at a wavelength of $412 \mathrm{~nm}$ (Tables 2, 3 and Fig. 3).

Table 2

Results of the study of the linearity of the method of quantitative determination of the flavonoids of the extract of $\mathrm{Bu}-$ pleurum aureum in syrup

\begin{tabular}{|c|c|c|c|c|c|}
\hline No. & Sample weight, g & $\begin{array}{c}\text { Actually entered } \\
(\mathrm{Xi}, \%)\end{array}$ & Optical density (A) & Determined (Yi \%) & Determined $\mathrm{Zi}=100(\mathrm{Yi} / \mathrm{Xi})$ \\
\hline 1 & 0.1604 & 80.20 & 0.140 & 80.11 & 99.89 \\
\hline 2 & 0.1702 & 85.10 & 0.158 & 85.21 & 100.13 \\
\hline 3 & 0.1801 & 90.05 & 0.177 & 90.21 & 100.18 \\
\hline 4 & 0.1904 & 95.20 & 0.197 & 94.97 & 99.76 \\
\hline 5 & 0.2002 & 100.10 & 0.219 & 100.41 & 100.31 \\
\hline 6 & 0.2103 & 105.15 & 0.241 & 105.19 & 100.04 \\
\hline 7 & 0.2201 & 110.05 & 0.264 & 110.10 & 100.04 \\
\hline 8 & 0.2302 & 115.10 & 0.288 & 114.83 & 99.77 \\
\hline 9 & 0.2403 & 120.15 & 0.314 & 119.94 & 99.82 \\
\hline \multicolumn{5}{|c|}{ average $\mathrm{Z}, \%$} & 99.99 \\
\hline \multicolumn{5}{|c|}{ relative standard deviation, $\mathrm{Sz} \%$} & 0.19 \\
\hline \multicolumn{5}{|c|}{ relative confidence interval $\Delta \mathrm{z} \%=\mathrm{t}(95 \%, 8) * \mathrm{Sz}$} & 0.37 \\
\hline \multicolumn{5}{|c|}{ critical for convergence of results $\Delta$ as $\%$} & 1.60 \\
\hline \multicolumn{5}{|c|}{ systematic error $\delta \%$} & 0.01 \\
\hline \multicolumn{5}{|c|}{ criterion of statistical uncertainty of systematic error $\delta \%$} & 0.12 \\
\hline \multicolumn{5}{|c|}{ criterion of practical uncertainty of systematic error $\delta \%$} & 0.51 \\
\hline \multicolumn{5}{|c|}{ general conclusion about the methodology } & correct \\
\hline
\end{tabular}


Metrological characteristics of linear dependence

\begin{tabular}{|c|c|c|c|}
\hline Quantity & Value & Requirements & $\begin{array}{c}\text { Evaluation of the results } \\
\text { (maintained or not maintained) }\end{array}$ \\
\hline $\mathrm{b}$ & 0.9947 & & maintained \\
\hline $\mathrm{S}_{\mathrm{b}}$ & 0.0047 & & \\
\hline $\mathrm{a}$ & 0.5159 & & \\
\hline $\mathrm{S}_{\mathrm{a}}$ & 0.4755 & & \\
\hline $\mathrm{S}_{0}$ & 0.1823 & & maintained \\
\hline $\mathrm{RSD}$ & 13.6818 & & \\
\hline $\mathrm{r}$ & 0.9999 & $\geq 0.9981$ & \\
\hline
\end{tabular}

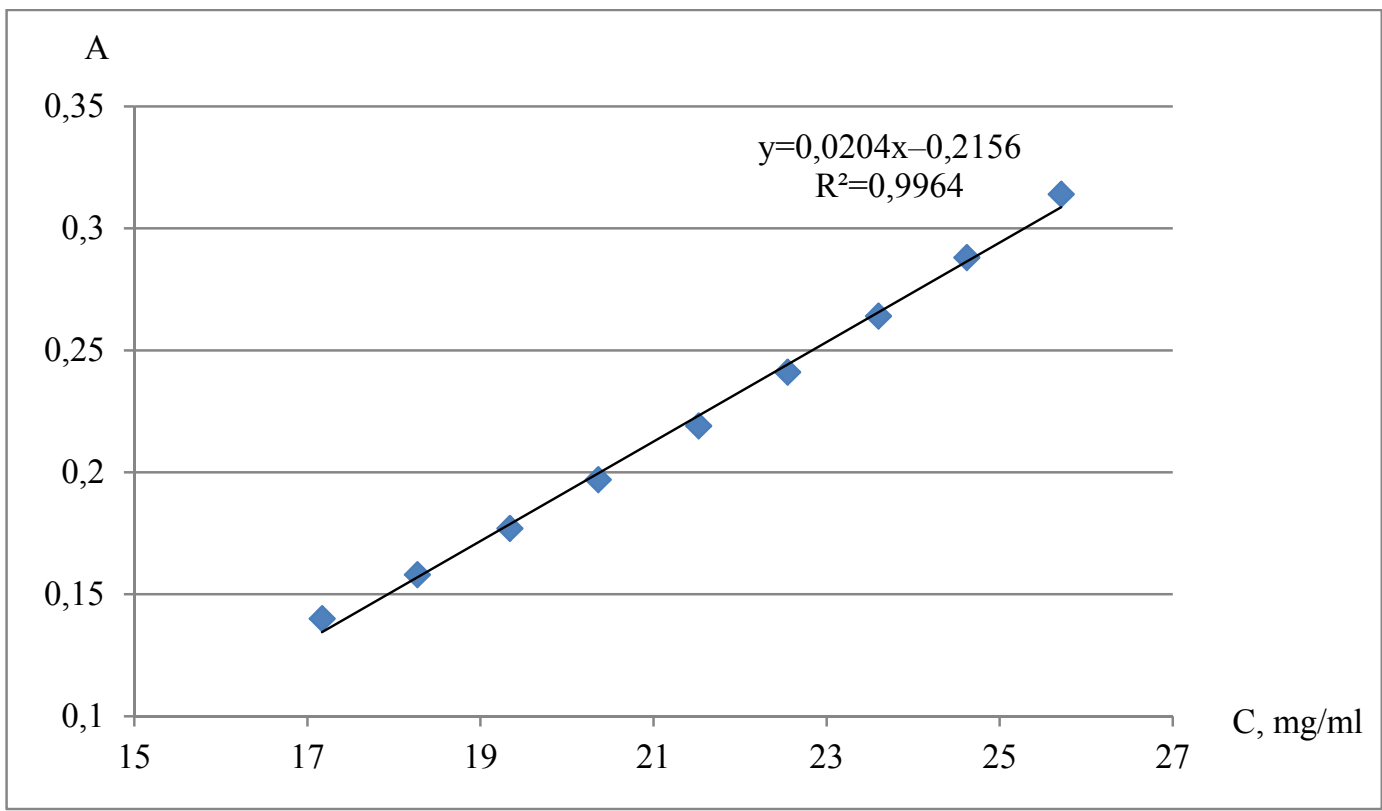

Fig. 3. Schedule of linear dependence of spectrophotometric method of quantitative determination of the amount of flavonoids of the extract of Bupleurum aureum in syrup

The obtained results indicate the presence of a linear dependence in the range of concentration of the amount of flavonoids from $80 \%$ to $120 \%$ in the extract of the Bupleurum aureum, as the value of the correlation coefficient (r) is 0.9999; the linear coefficient of linear dependence (b) is equal to 0.9947 , the free line of linear dependence (a) is 0.5159 .
It was found that the content of the amount of flavonoids in terms of rutin in syrup should be from $0.085 \%$ to $0.115 \%$.

Reproducibility of the procedure was established on six samples of the dosage form. The obtained metrological characteristics of the technique are given in Table 4.

Table 4

Metrological characteristics of the quantitative determination of the amount of flavonoids in Bupleurum aureum syrup in terms of rutin, determined by the spectrophotometric method, $\mathrm{P}(\mathrm{t}, \mathrm{v})=2,5706$

\begin{tabular}{|c|c|c|c|c|c|c|c|}
\hline $\mathrm{n}$ & $\begin{array}{l}\text { Number of found BAS } \\
\text { equivalent to rutin, } \%\end{array}$ & $\mathrm{X}_{\text {cep }}$ & $\mathrm{S}^{2}$ & $\mathrm{~S}$ & $\mathrm{~S}_{\text {Xaver }}$ & $\Delta \mathrm{X}$ & $\bar{\varepsilon}, \%$ \\
\hline \multirow{6}{*}{6} & 0.1120 & \multirow{6}{*}{0.1005} & \multirow{6}{*}{0.0001} & \multirow{6}{*}{0.0117} & \multirow{6}{*}{0.0048} & \multirow{6}{*}{0.0039} & \multirow{6}{*}{3.91} \\
\hline & 0.0991 & & & & & & \\
\hline & 0.0997 & & & & & & \\
\hline & 0.0879 & & & & & & \\
\hline & 0.0882 & & & & & & \\
\hline & 0.1160 & & & & & & \\
\hline
\end{tabular}

7. Conclusions from the conducted research and prospects for further development of this field

1. The HPLC method established the presence of a Bupleurum aureum of the flavonoid structure in the dry extract of the above-ground part. The highest content of isoquercitrin has caused the use of a standard rutin sample due to the same aglycones.

2. A spectrophotometric method of quantitative determination of the amount of flavonoids equivalent to rutin in the combined dosage form of a syrup in the pres- 
ence of another active ingredient of loratadine in the visible region is developed.

3. Validation characteristics (specificity, linearity, correctness and precision) of the proposed methodology were studied and an evaluation was made regarding the eligibility criteria.

\section{References}

1. Protokoly provizora (farmatsevta) pry vidpusku bezretsepturnykh likarskykh zasobiv. 1.1.1. Symptomatychne likuvannia alerhii: Nakaz MOZ Ukrainy No. 838. 18.12.2007.

2. Olennikov D. N., Partilkhaev V. V. Flavonoids and phenylpropanoids from several species of Bupleurum growing in Buryatia // Chemistry of Natural Compounds. 2013. Vol. 48, Issue 6. P. 1078-1082. doi: http://doi.org/10.1007/s10600-013-0471-x

3. Hepatoprotective and antioxidant effects of Bupleurum kaoi Liu (Chao et Chuang) extract and its fractions fractionated using supercritical CO2 on CCl4-induced liver damage / Wang B.-J. et. al. // Food and Chemical Toxicology. 2004. Vol. 42 , Issue 4. P. 609-617. doi: http://doi.org/10.1016/j.fct.2003.11.011

4. Doslidzhennia farmakodynamiky vodnoho ta spyrtovoho ekstraktiv laskavtsia zolotystoho / Naboka O. I. et. al. // Klinichna farmatsiia. 2014. Vol. 18, Issue 4. P. 58-61.

5. Issledovanie soderzhaniya i sostava flavonoidov i fenilkarbonovykh kislot rasteniy roda Bupleurum L., kul'tivirovannykh v Belarusi / Biryukova N. M. et. al. // Vestnik farmatsii. 2011. Issue 4 (54). P. $23-30$.

6. Jiang X.-J., Tang J.-C., Bay H.-J. Visible Spectrophotometric Determination of Total Flavonoids in Capparis spinosa L. Buds // Food Science. 2010. Vol. 31, Issue 18. P. 252-254.

7. Wan D., Chen Y., Wang J. Determination of total flavonoids in three Sedum crude drugs by UV-Vis spectrophotometry // Pharmacognosy Magazine. 2010. Vol. 6, Issue 24. P. 259-263. doi: http://doi.org/10.4103/0973-1296.71784

8. Sposib kilkisnoho vyznachennia flavonoidiv u nadzemnii chastyni laskavtsia zolotystoho: Pat. No. 88494 UA. MPK: G01J 3/30, G01N 21/00 / Hlushchenko A. V., Heorhiiants V. A., Bevz N. Yu. No. u201306849; declareted: 31.05.2013; published: 25.03.2014; Bul. No. 6. 3 p.

9. Derzhavna Farmakopeia Ukrainy. Vol. 1. Kharkiv: Derzhavne pidpryiemstvo «Ukrainskyi naukovyi farmakopeinyi tsentr yakosti likarskykh zasobiv», 2015. 1128 p.

10. Glushchenko A. V., Georgiyants V. A., Bevz N. Yu. Development and evaluation of validation characteristics of the quantitative determination method for loratadine in the syrup // New of Pharmacy. 2014. Issue 1 (77). P. 31-35. doi: http://doi.org/10.24959/nphj.14.1930

Дата надходження рукопису 22.01.2019

Alla Glushchenko, PhD, Associate Professor, Department of Quality, Standardization and Certification of Medicines, National University of Pharmacy, Pushkinska str., 53, Kharkiv, Ukraine, 61002

E-mail: allaglushchenko05@gmail.com

Ivan Bezruk, Postgraduate Student, Department of Pharmaceutical Chemistry, National University of Pharmacy Pushkinska str., 53, Kharkiv, Ukraine, 61002

E-mail: vania.bezruk@gmail.com

Nataliia Bevz, PhD, Associate Professor, Department of Pharmaceutical Chemistry, National University of Pharmacy, Pushkinska str., 53, Kharkiv, Ukraine, 61002

E-mail: nata.bevz.60@gmail.com

Liudas Ivanauskas, PhD, Associate Professor, Head of Department, Department of Analytical and Toxicological Chemistry, Lithuanian University of Health Sciences, A. Mickevičiaus g. 9, Kaunas, Lithuania, LT-44307 E-mail: liudas.ivanauskas@1smuni.lt

Victoriya Georgiyants, Doctor of Pharmaceutical Sciences, Professor, Head of Department, Department of Pharmaceutical Chemistry, National University of Pharmacy, Pushkinska str., 53, Kharkiv, Ukraine, 61002 E-mail: vgeor@ukr.net 